\title{
PENGARUH KOMPENSASI DAN BEBAN KERJA TERHADAP LOYALITAS KARYAWAN DI DEPARTEMEN OPERASI PT. PUPUK SRIWIDJAJA PALEMBANG
}

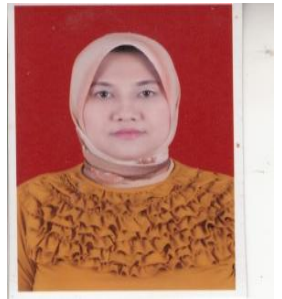

Oleh:

Agustina Heryati S.Kom.,MM

Dosen Fasilkom UIGM Palembang

Email : agustinaharyati@yahoo.com

\begin{abstract}
Abstraksi
Tujuan dari penelitian ini untuk mengetahui apakah kompensasi dan beban kerja secara signifikan mempengaruhi loyalitas karyawan. Populasi dalam penelitian ini adalah karyawan Departemen Operasi PT. Pupuk Sriwidjaja Palembang. Teknik pengambilan sampel adalah simple random sampling dengan menggunakan rumus Slovin yang dapat sebanyak 102 responden dalam metode penelitian dengan menggunakan analisis regresi linier berganda. Hasil penelitian dan hipotesis menunjukkan bahwa secara simultan dan parsial kompensasi dan beban kerja secara signifikan mempengaruhi kinerja karyawan. Para pemimpin Departemen Operasi, harus memperhatikan kompensasi dan beban kerja untuk hasil yang optimal dalam mencapai tujuan organisasi.
\end{abstract}

Kata Kunci; Kompensasi, beban kerja, Loyalitas karyawan

\section{PENDAHULUAN}

\subsection{Latar Belakang Masalah}

PT Pupuk Sriwidjaja Palembang terdiri dari empat direktorat yaitu Direktorat Produksi, Direktorat Komersil, Direktorat Teknik dan Pengembangan,dan Direktorat SDM dan Umum. Direktorat Produksi terdiri dari tiga Departemenyaitu Departemen Pemeliharaan, Departemen Operasional, dan DepartemenTeknologi. Departemen Operasional membawahi lima Dinas, yaitu Dinas Operasi1B, Dinas Operasi 2B, Dinas Operasi 3, Dinas Operasi 4 dan Dinas pengantongan dimana masing-masing dinas Operasi membawahi 3 bagian yaitu, Bagian Ammonia, Bagian Urea dan Bagian Utilitas. (Sumber: Sistem Informasi PT Pusri Palembang).

Dalam meningkatkan kinerja dan loyalitas karyawan, perusahaan melakukan beberapa cara yang dapat mendorong karyawan untuk bekerja secara maksimal. Beberapa kegiatan tersebut diantaranya memberikan pelatihan, pemberian kompensasi, pemberian penghargaan dan lain sebagainya. Kepuasan akan kompensasi dapat mempengaruhi perilaku karyawan untuk bekerja lebih bersemangat dan memacu tingginya kinerja (Handoko, 2000:193). Kompensasi bagi karyawan berbeda satu dengan lainnya sesuai dengan jabatan dan posisi dimana mereka bekerja. Untuk karyawan di Departemen Operasi akan mendapatkan tunjangan lebih seperti tunjangan shift, yaitu tunjangan kerja akibat beban dari waktu kerja shift (waktu kerja 8 jam di waktu pagi, sore ataupun malam hari), dan tunjangan resiko diperuntukkan karena tingginya tingkat resiko kecelakaan di Departemen Operasi dibandingkan dengan Departemen lainnya. Gaji yang didapat oleh karyawan pabrik berbanding karyawan non pabrik pada level kepangkatan yang sama untuk level pelaksana adalah $129 \%$, sedangkan untuk pimpinan muda karyawan pabrik berbanding karyawan non pabrik lebih 
tinggi 121,5\%. (Sumber : data diolah dari Surat Kep Dir N0:SK/Dir/357/2015).

Khusus di Departemen Operasi mengharuskan kerja shift, serta kerja lembur (overtime) apabila dibutuhkan terutama kondisi operasi pabrik tidak stabil. Kondisi kerja lembur yang berturut turut dalam jangka waktu lama membuat karyawan lelah baik secara fisik maupun psikis menjadi beban kerja karyawan. Hal ini sangat mempengaruhi kinerja karyawan. Karyawan pabrik dituntut mempunyai kekuatan fisik yang baik karena harus bekerja dengan menggunakan fisik dalam kegiatan operasional seharihari. Kegiatan banyak dilaksanakan langsung dilapangan yang berhadapan langsung dengan mesin operasional. Beban kerja merupakan kondisi pekerjaan yang dirasakan oleh pekerja yang berkaitan dengan faktor situasional yang terdiri dari faktor lingkungan fisik dan psikis (Cohen, 1980). Karyawan dilingkungan pabrik dituntut untuk melaksanakan kerja pada jam tertentu yang telah diatur oleh perusahaan. Hal ini tentunya juga sangat mempengaruhi beban kerja yang harus diterima karyawan karyawan. Hari kerja dan jam kerja karyawan PT. PUSRI Palembang:

\section{a. Kerja Shift}

Shift Pagi : jam 07:00 s.d. 15:00

Shift Sore : jam 15:00 s.d. 23:00

Shift Malam : jam 23:00 s.d. 07:00

b. Kerja Non Shift

Senin - Kamis : 07:30 s.d. 16:30 (12:00 13:00 Istirahat)

Jumat : 07:30 s.d. 17:00 (11:30 - 13:00

Istirahat)

(Sumber : PKB PT. PUSRI Palembang 2015-2017)
Perpindahan karyawan yang terjadi di PT. Pusri Palembang tidak hanya dari PT. Pusri Palembang ke perusahaan lain tetapi juga banyak terjadi perpindahan karyawan dari satu bagian kebagian lainnya. Yang sering terjadi adalah perpindahan karyawan dari Departemen Operasi ke Departemen non Operasi. Ini akibat dari menurutnya tingkat loyalitas karyawan terhadap unit kerjanya. Tingkat perpindahan karyawan yang tinggi akan mengganggu jalannya aktifitas kerja, sebab di dalam suatu perusahaan setiap karyawan menempati posisinya dan mengerjakan pekerjaannnya masing- masing sehingga kekosongan terhadap suatu posisi akan memperlambat jalannya pelaksanaan pekerjaan. Jumlah karyawan Departemen Operasi yang berhenti (resign) dari tahun 20012 - 2015 sebanyak 8 orang, dan Jumlah karyawan pabrik yang pindah ke bagian diluar Departemen Operasi sebanyak 63 orang. (Sumber SI PT Pusri Palembang s/d Agustus 2015).

Loyalitas karyawan yang tinggi terhadap perusahaan tidak akan tumbuh begitu saja apabila kondisi dan perlakuan perusahaan terhadap karyawan tidak ikut mendukungnya. Apabila suatu perusahaan mengalami keadaan dimana loyalitas karyawannya rendah atau mengalami penurunan maka sudah sewajarnya jika perusahaan mengadakan introspeksi diri mengenai faktor- faktor yang mungkin menjadi penyebabnya.

Pemberian kesejahteraan akan menciptakan ketenangan, semangat kerja, dedikasi, disiplin dan sikap loyal karyawan terhadap perusahaan sehingga labour turnover relative rendah (Hasibuan, 2007:187).

Dari fenomena di atas dapat disimpulkan bahwa perlunya perusahaan memperhatikan kesejahteraan karyawan 
dan beban kerja karyawan, yang dapat berpengaruh pada kepuasan kerja dan loyalitas terhadap unit kerjanya sehingga karyawan dapat memberikan kontribusi yang maksimal kepada perusahaan.

Penulis tertarik untuk meneliti mengenai loyalitas karyawan di perusahaan PT. Pusri Palembang khususnya yang berada di departemen operasi, karena melihat fenomena di sekitarnya dimana terdapat orang - orang yang berdedikasi pada perusahaan tempat mereka bekerja, dan bekerja secara maksimal serta memiliki loyalitas yang tinggi namun setelah sekian lama bekerja memilih untuk resign ataupun berpindah kebagian lain diluar Departemen Operasi. Berdasarkan permasalah diatas maka judul yang diangkat adalah "PENGARUH KOMPENSASI DAN BEBAN KERJA TERHADAP LOYALITAS KARYAWAN DI DEPARTEMEN OPERASI PT. PUPUK SRIWIDJAJA PALEMBANG".

\subsection{Rumusan Masalah}

1. Apakah kompensasi beban kerja berpengaruh terhadap loyalitas karyawan di Departemen Operasi PT Pusri Palembang baik secara simultan maupun secara parsial?

2. Variabel manakah dari kompensasi dan beban kerja yang berpengaruh paling dominan terhadap loyalitas karyawan di Departemen Operasi PT Pusri Palembang?

\subsection{Tujuan Penelitian}

1. Untuk mengetahui apakah kompensasi dan beban kerja berpengaruh secara simultan dan parsial terhadap loyalitas karyawan di Departemen Operasi PT. Pusri Palembang.

2. Untuk mengetahui variabel yang berpengaruh paling dominan terhadap loyalitas karyawan di Departemen Operasi PT. Pusri Palembang.

\subsection{Manfaat Penelitian}

1. Manfaat Teoritis; dapat dijadikan sebagai sarana informasi untuk meningkatkan wawasan dan pengetahuan tentang sejauh mana pengaruh kompensasi dan dan beban kerja terhadap loyalitas karyawan di Departemen Operasi PT. Pupuk Sriwidjaja Palembang.

2. Manfaat Praktis; dapat dijadikan sebagai sumbangan pemikiran bagi parapengambil kebijakan di PT. Pusri Palembang khususnya di Departemen Operasi dalam rangka untuk meningkatkan loyalitas karyawan. Penelitian ini juga diharapkan dapat menyumbangkan pengembangan keilmuan untuk peneliti selanjutnya, terutama yang berhubungan dengan pengaruh kompensasi dan beban kerja terhadap loyalitas karyawan di suatu perusahaan.

\section{STUDI KEPUSTAKAAN \\ 2.1 Landasan Teori}

\subsubsection{Pengertian Kompensasi}

Menurut Mathis \& Jackson (2006:419), kompensasi merupakan faktor penting yang mempengaruhi bagaimana dan mengapa orang-orang memilih bekerja di sebuah organisasi dari pada yang lain. Para pemberi kerja harus agak kompetitif dengan beberapa jenis kompensasi untuk menarik dan mempertahankan karyawan yang kompeten. Dessler (2015:417), kompensasi karyawan (employee compensation) meliputi semua bentuk bayaran yang diberikan kepada karyawan dan timbul dari hubungan kerja mereka. Kompensasi karyawan memiliki dua komponen utama, yaitu pembayaran 
finansial langsung atau direct financial payments (upah, gaji, insentif, komisi dan bonus) dan pembayaran finansial tidak langsung atau indirect financial payments (tunjangan finasial seperti ansuransi dan liburan yang dibayar oleh pemberi kerja).

\subsubsection{Jenis-jenis Kompensasi}

Kompensasi terdiri dari kompensasi langsung dan tidak langsung (Rivai, 2013:741).

1) Kompensasi langsung (direct compensation), terdiri dari:

a. Gaji pokok yang merupakan kompensasi dasar yang diterima seorang karyawan biasanya berupa upah atau gaji.

b. Penghasilan tidak tetap merupakan jenis kompensasi yang dihubungkan dengan kinerja individual, tim, atau dengan suatu organisasional.

2) Kompensasi tidak langsung (indirect compensation), diantaranya:
a. Tunjangan karyawan
b. Tunjangan jabatan

\subsubsection{Tujuan-tujuan Kompensasi}

Menurut Handoko (2008:156) tujuan pemberian kompensasi sebagai berikut:

1) Memperoleh personalia yang qualified.

2) Mempertahankan para karyawan yang ada sekarang.

3) Menjamin keadilan.

4) Menghargai perilaku yang diinginkan.

5) Mengendalikan biaya-biaya.

6) Memenuhi peraturan-peraturan legal.

\subsubsection{Indikator Kompensasi}

Menurut Simamora (2004:445) indikator kompensasi karyawan yaitu:

1) Gaji yang adil sesuai dengan pekerjaan.

2) Insentif yang sesuai dengan pengorbanan.

3) Tunjangan yang sesuai dengan harapan.
4) Fasilitas yang memadai.

\subsubsection{Pengertian Beban Kerja}

Gawron (2008:87) mendefinisikan beban kerja sebagai berikut: "Workload has been defined as a set of task demands, as effort, and as activity or accomplishment", yang berarti bahwa beban kerja telah didefinisikan sebagai seperangkat tuntutan tugas, sebagai upaya, dan sebagai kegiatan atau prestasi.

Schultz dan Schultz (2006:366) menyatakan beban kerja sebagai berikut: "Work overload is too much to perform in the time available or work that is too difficult for the employee to perform", yang berarti bahwa beban kerja adalah terlalu banyak melakukan pekerjaan pada waktu yang tersedia atau melakukan pekerjaan yang terlalu sulit untuk karyawan.

Menurut Kirmeyer \& Dougherty (1988), beban kerja yang berlebihanpun akan mempengaruhi kepuasan kerja karyawan dan kinerja kryawan. Hal tersebut bisa berdampak terhadap loyalitas karyawan.

Bridger (2001:184) menyatakan bahwa " Mental workload is a way of describing the mental stress and strain of being busy at work. Excessive 'mental workload' often leads to mistakes, misunderstandings, omissions and other errors, these include: remembering to do things and formulation and implementation of plans of actions", yang berarti bahwa beban kerja mental adalah cara yang menggambarkan tekanan mental dan ketegangan pada saat sibuk bekerja. Beban kerja mental yang banyak sering menyebabkan kesalahan, kesalahpahaman, kelalaian dan kesalahan lainnya, misalnya mengingat untuk melakukan sesuatu dan 
penyusunan dan pelaksanaan rencana tindakan.

Robbins (2007:90) menyatakan bahwa positif negatifnya beban kerja merupakan masalah persepsi. Persepsi didefinisikan sebagai suatu proses dimana individu mengorganisasikan dan menafsirkan kesan indera mereka agar memberi makna kepada lingkungan mereka (Robbins, 2007:160).

Beban kerja terdiri atas tiga dimensi atau faktor yaitu beban waktu (time load) yaitu banyaknya waktu yang tersedia dalam melaksanakan suatu pekerjaan, beban mental (mental effort load) yaitu banyaknya usaha mental dalam melaksanakan suatu pekerjaan, dan beban psikologis (psychological stress load) yang menunjukkan tingkat resiko pekerjaan, kebingungan dan frustasi (Reid et al, 1981).

\subsubsection{Faktor-Faktor Yang Mempengaruhi Beban Kerja}

Faktor-faktor yang mempengaruhi beban kerja dalam Jurnal Arika (2011:85) adalah sebagai berikut :

1. Faktor eksternal:

a. Tugas (Task).

b. Organisasi kerja.

c. Lingkungan kerja.

2. Faktor internal: faktor yang berasal dari dalam tubuh akibat dari reaksi beban kerja eksternal yang berpotensi sebagai stressor, meliputi faktor somatis (jenis kelamin, umur, ukuran tubuh, status gizi, kondisi kesehatan, dan sebagainya), dan faktor psikis (motivasi, persepsi, kepercayaan, keinginan, kepuasan, dan sebagainya).

\subsubsection{Pengertian Loyalitas Kerja}

Wicaksono (2013:48) menyatakan loyalitas adalah setia pada sesuatu dengan rasa cinta, sehingga dengan rasa loyalitas yang tinggi sesorang merasa tidak perlu untuk mendapatkan imbalan dalam melakukan sesuatu untuk orang lain/perusahaan tempat dia meletakan loyalitasnya. Menurut Hasibuan (2011:95), Kesetiaan dicerminkan oleh kesediaan karyawan menjaga dan membela organisasi di dalam maupun di luar pekerjaan dari rongrongan orang yang tidak bertanggung jawab. Menurut Reichheld, semakin tinggi loyalitas para karyawan di suatu organisasi, maka semakin mudah bagi organisasi itu untuk mencapai tujuan-tujuan organisasi yang telah ditetapkan sebelumnya oleh pemilik organisasi. Begitu pula sebaliknya, bagi organisasi yang loyalitas para karyawannya rendah, maka semakin sulit bagi organisasi tersebut untuk mencapai tujuan-tujuan organisasinya yang telah ditetapkan sebelumnya oleh para pemilik organisasi.

\subsubsection{Aspek-Aspek Loyalitas Kerja}

Aspek-aspek loyalitas kerja yang terdapat pada individu dikemukakan oleh Siswanto (2010:112), yang menitik beratkan pada pelaksanaan kerja yang dilakukan karyawan antara lain. :

a. Taat pada peraturan.

b. Tanggung jawab pada perusahaan.

c. Kemauan untuk bekerja sama.

d. Rasa memiliki.

e. Hubungan antar pribadi.

f. Kesukaan terhadap pekerjaan.

\subsubsection{Faktor-Faktor Yang} Mempengaruhi Loyalitas Kerja

Steers dan Porter (1983) menyatakan bahwa timbulnya loyalitas kerja dipengaruhi oleh faktor-faktor :

a. Karakteristik pribadi.

b. Karakteristik pekerjaan.

c. Karakteristik desain perusahaan. 
d. Pengalaman yang diperoleh dalam perusahaan.

\subsubsection{Indikator Loyalitas Karyawan}

Ada 16 indikator yang dapat dipakai untuk mengidentifikasi loyalitas karyawan sebagaimana dikemukakan Powers (2000), yaitu:

1. Tetap bertahan dalam organisasi.

2. Bersedia bekerja lembur untuk menyelesaikan pekerjaan.

3. Menjaga rahasia bisnis perusahaan.

4. Mempromosikan organisasinya kepada pelanggan dan masyarakat umum.

5. Menaati peraturan tanpa perlu pengawasan yang ketat.

6. Mau mengorbankan kepentingan pribadi demi kepentingan organisasi.

7. Tidak bergosip, berbohong atau mencuri.

8. Membeli dan menggunakan produk perusahaan.

9. Ikut berkontribusi dalam kegiatan sosial organisasi.

10. Menawarkan saran-saran untuk perbaikan.

11. Mau berpartisipasi dalam kegiatankegiatan aksidental organisasi.

12. Mau mengikuti arahan atau instruksi.

13. Merawat properti organisasi dan atau tidak memboroskannya.

14. Bekerja secara aman.

15. Tidak mengakali aturan organisasi termasuk ijin sakit.
16. Mau bekerja sama dan membantu rekan kerja.

\subsubsection{Dimensi Loyalitas}

Loyalitas memiliki dua dimensi: internal dan external. Loyalitas pada dasarnya adalah keterikatan emosional. Dimensi internal adalah komponen emosional yang meliputi rasa peduli (feeling of caring), rasa kedekatan (feeling of affiliation), dan rasa akan tanggung jawab (feeling of commitment). Dimensi eksternal terdiri dari perilaku yang menampilkan komponen emosional dan merupakan bagian dari loyalitas yang paling banyak berubah (Mehta et al, 2010:98).

\subsection{Hubungan Antar Variabel}

\subsubsection{Hubungan Kompensasi dengan} Loyalitas Karyawan

Menurut Steers \& Porter (1983:520), loyalitas kerja akan tercipta apabila karyawan merasa tercukupi dalam memenuhi kebutuhan hidup dari pekerjaannya, sehingga mereka betah bekerja dalam suatu perusahaan.

\subsubsection{Hubungan Beban Kerja dengan Loyalitas Karyawan}

Menurut Kirmeyer \& Dougherty (Ronald E. Regiao, 2002), beban kerja yang berlebihanpun akan mempengaruhi kepuasan kerja pegawai dan kinerja pegawai. Hal tersebut bisa berdampak terhadap loyalitas karyawan. 


\subsection{Penelitian Terdahulu}

Tabel 2.1 Penelitian Terdahulu

\begin{tabular}{|c|c|c|c|c|}
\hline No & Judul Penelitian & Hasil Penelitian & Persamaan & Perbedaan \\
\hline 1 & $\begin{array}{l}\text { Pengaruh kompensasi } \\
\text { terhadap loyalitas } \\
\text { karyauan PT. Putera } \\
\text { Lautan KumalaLines } \\
\text { Samarinda(Rahmadana } \\
\text { Safitri: } 2015 \text { ) }\end{array}$ & $\begin{array}{l}\text { Kompensasi } \\
\text { berpengaruh } \\
\text { signifikan terha dap } \\
\text { loyalitas, dan } \\
\text { pemberian kompensasi } \\
\text { sebaiknya dilihat juga } \\
\text { dari prestasi } \\
\text { karyawan, dan tidak } \\
\text { hanya dari status } \\
\text { karyawan. }\end{array}$ & $\begin{array}{l}\text { Variabel } \\
\text { independen } \\
\text { adalah } \\
\text { kompensasi } \\
\text { serta variabel } \\
\text { dependen } \\
\text { adalah loyalitas. }\end{array}$ & $\begin{array}{l}\text { Tidak ada } \\
\text { variabel } \\
\text { lingkungan } \\
\text { kerja dan } \\
\text { beban kerja } \\
\text { sebagai } \\
\text { variabel } \\
\text { independen }\end{array}$ \\
\hline 2 & $\begin{array}{l}\text { Pengaruh insentif } \\
\text { terhadap loyalitas(Ni } \\
\text { Made Maharani, Kusdi } \\
\text { Rahardjo, M Djudu } \\
\text { Mukzam : 2013) }\end{array}$ & $\begin{array}{l}\text { Pengaruh paling } \\
\text { dominan terhadap } \\
\text { loyali tas karyauan } \\
\text { adalah insentif materil, } \\
\text { hal ini dapat menjadi } \\
\text { suatu tantangan bagi } \\
\text { perusahaan untuk } \\
\text { berusaha } \\
\text { meningkatkan } \\
\text { pemberian insentif non } \\
\text { materil. }\end{array}$ & $\begin{array}{l}\text { Loyalitas } \\
\text { sebagai } \\
\text { variabel } \\
\text { dependen. }\end{array}$ & $\begin{array}{l}\text { Tidak ada } \\
\text { variabel } \\
\text { independen } \\
\text { beban kerja } \\
\text { dan } \\
\text { lingkungan } \\
\text { kerja. }\end{array}$ \\
\hline 3 & $\begin{array}{l}\text { Pengaruh kompensasi, } \\
\text { lingkungan kerja dan } \\
\text { beban kerja terhadap } \\
\text { loyalitas karyawan } \\
\text { melalui kepuasan } \\
\text { kerja(Adhitia } \\
\text { Pratama 1, Sri } \\
\text { Suryoko2, } \\
\text { Widiartanto3: 2015) }\end{array}$ & $\begin{array}{l}\text { Secara simultan } \\
\text { variabel kompensasi, } \\
\text { lingkungan kerja, dan } \\
\text { beban kerja tethadap } \\
\text { variabel loyalitas } \\
\text { karyawan melalui } \\
\text { kepuasan kerja } \\
\text { memberikan pengaruh } \\
\text { yang positif dan } \\
\text { signifikan. }\end{array}$ & $\begin{array}{l}\text { Kompensasi, } \\
\text { lingkunan kerja } \\
\text { dan beban kerja } \\
\text { sebagai variabel } \\
\text { independen serta } \\
\text { Loyalitas sebagai } \\
\text { variabel } \\
\text { dependen. }\end{array}$ & $\begin{array}{l}\text { Kepuasan } \\
\text { kerja } \\
\text { sebagai } \\
\text { variabel } \\
\text { dependen. }\end{array}$ \\
\hline 4 & $\begin{array}{l}\text { Pengaruh pengalaman } \\
\text { kerja dan } \\
\text { kepemimpinan } \\
\text { transformation terhadap } \\
\text { loyalitas karyawan. } \\
\text { (Ni Putu Eka Fajariani, } \\
\text { I.B Ketut Surya:2015) }\end{array}$ & $\begin{array}{l}\text { Pengalaman kerja dan } \\
\text { kepemimpinan } \\
\text { transformational } \\
\text { secara simultan dan } \\
\text { partial memiliki } \\
\text { pengaruh yang positif } \\
\text { dan signifikan } \\
\text { terhadap loyalitas } \\
\text { karyawan. }\end{array}$ & $\begin{array}{l}\text { Loyalitas sebagai } \\
\text { variabel } \\
\text { dependen. }\end{array}$ & $\begin{array}{l}\text { Tidak ada } \\
\text { variabel } \\
\text { independen } \\
\text { kompensasi, } \\
\text { lingkungan } \\
\text { kerja dan } \\
\text { beban kerja. }\end{array}$ \\
\hline
\end{tabular}

\subsection{Kerangka Konseptual Penelitian}

Alur pikir atau kerangka berfikir merupakan model konseptual tentang bagaimana teori berhubungan dengan faktor yang telah diidentifikasikan sebagai masalah penting (Sugiyono, 2014). 


\section{Gambar 2.1 Kerangka Konseptual Penelitian}

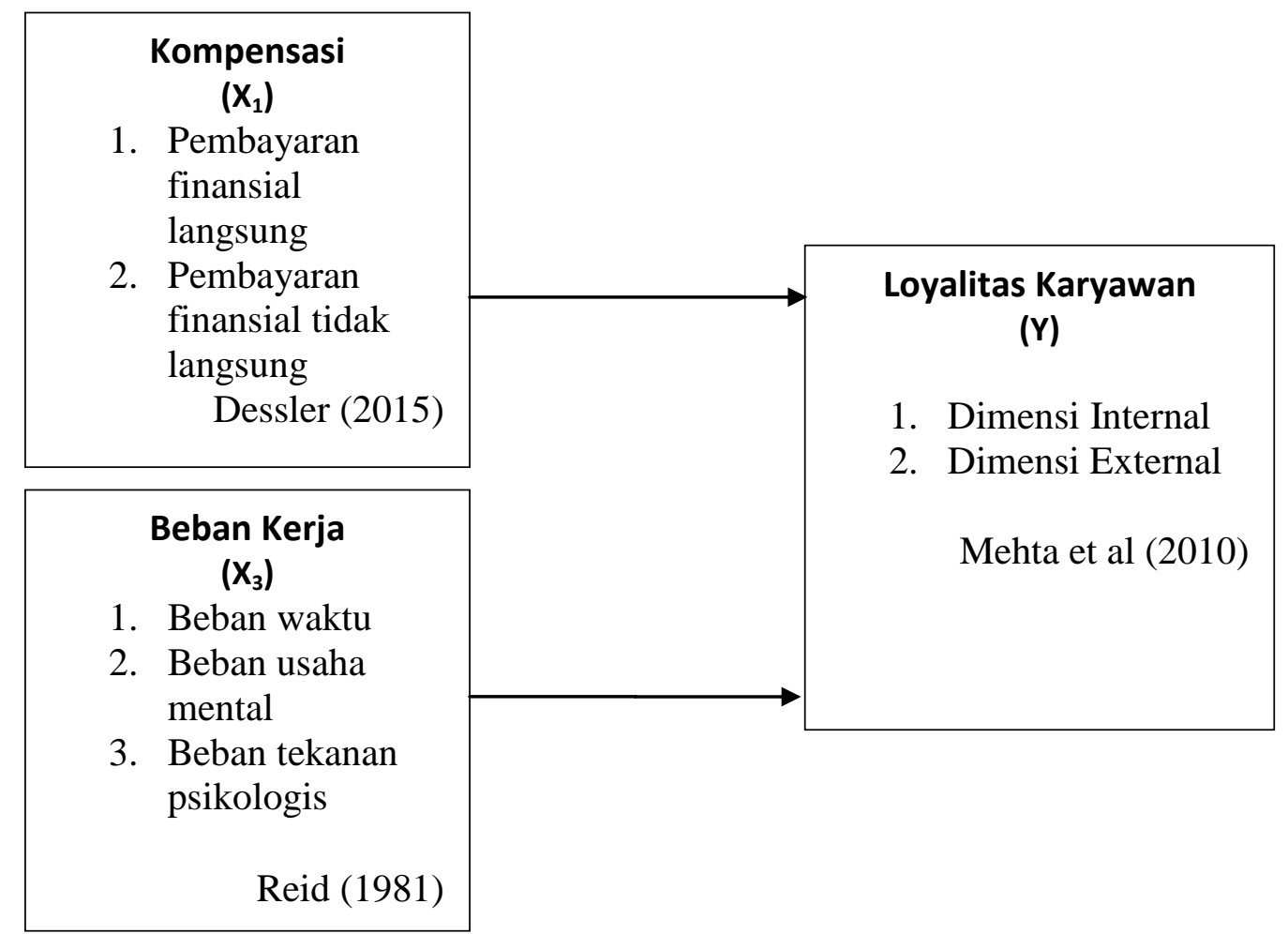

\subsection{Hipotesis Penelitian}

H1 : Kompensasi berpengaruh terhadap loyalitas karyawan.

$\mathrm{H} 2$ : Lingkungan kerja berpengaruh terhadap loyalitas karyawan.

H3 : Beban kerja berpengaruh terhadap loyalitas karyawan.

H4 : Kompensasi, lingkungan kerja dan beban kerja secara simultan berpengaruh terhadap loyalitas karyawan.

H5 : Kompensasi berpengaruh dominan terhadap loyalitas karyawan.

\section{METODE PENELITIAN}

\subsection{Rancangan Penelitian}

Penelitian ini bertujuan menguji hipotesis, untuk mengetahui pengaruh antar variabel dengan mengacu pada rumusan masalah yang telah ditetapkan serta tujuan penelitian yang diharapkan. Berdasarkan uraian tersebut maka dalam penelitian ini menempatkan kompensasi $\left(\mathrm{X}_{1}\right)$ dan beban kerja $\left(\mathrm{X}_{2}\right)$ sebagai variabel bebas atau independen, serta loyalitas (Y) sebagai variabel terikat atau dependen.

Paradigma regresi linier berganda tersebut menggambarkan besarnya hubungan $\mathrm{X}_{1}$ dengan $\mathrm{Y}, \mathrm{X}_{2}$ dengan $\mathrm{Y}, \mathrm{X}_{3}$ dengan $\mathrm{Y}$. Dan mencari besarnya $X_{1}, X_{2}, X_{3}$ terhadap $Y$ secara bersama-samaan, digunakan metode regresi linier berganda. Data dikelola dengan alat uji statistik dengan menggunakan program SPSS.

\subsection{Tempat dan Waktu}

Penelitian ini dilaksanakan di PT Pupuk Sriwidjaja Palembang, yang berlokasi di Jalan Mayor Zen Palembang. Waktu penelitian ini dimulai pada awal bulan Juli sampai dengan akhir bulan Desember 2015.

\subsection{Populasi dan Sampel}

Penelitian ini menggunakan teknik stratified random sampling di lingkungan 
Departemen Operasi PT Pupuk Sriwidjaja Palembang dengan jumlah sampel sebesar 102 pegawai dari jumlah total 655 karyawan.

\subsection{Jenis dan Sumber Data}

\subsubsection{Jenis Data}

1. Data Kualitatif; yaitu data yang disajikan berupa keterangan penjelasan dan pembahasan teori. Data kualitatif berupa hasil pengamatan peneliti, dan masukan dari wawancara langsung dengan karyawan (Muhadjir, 1996:2).

2. Data Kuantitatif; yaitu data berupa angka-angka yang pembahasannya melalui perhitungan statistik berdasarkan jawaban kuesioner dari responden. Data kuantitatif pada penelitian ini adalah data karyawan untuk menentukan populasi dan jumlah sampel (Sugiyono 2010:15).

\subsubsection{Sumber Data}

1. Data Sekunder; yaitu data yang diperlukan untuk mendukung hasil penelitian yang berasal dari literature, artikel dan berbagai sumber lainnya yang berhubungan dengan penelitian.

2. Data Primer; data yang diperoleh langsung meliputi dokumen-dokumen perusahaan dan lain-lain yang berhubungan dengan penelitian. Data primer dikumpulkan dan diolah sendiri oleh peneliti langsung dari responden berupa kuesioner yang disebarkan. Kuesioner berisi daftar pertanyaan yang terstruktur dan materinya berhubungan dengan kompensasi dan beban kerja serta pengaruhnya terhadap loyalitas karyawan.

\subsection{Metode Pengumpulan Data}

Teknik pengumpulan data dalam penelitian ini adalah menggunakan kuesioner yang disebarkan kepada karyawan Departemen Operasi di PT. Pusri Palembang. Responden menjawab sendiri tanpa adanya intervensi peneliti. Pertanyaan dalam kuesioner tertutup dibuat dengan menggunakan skala likert dalam interval 1-5 untuk kategori-kategori pertanyaan dengan jawaban sangat tidak setuju dengan nilai 1 (satu) sampai dengan sangat setuju dengan nilai 5 (lima).

\subsection{Teknik Analisis Data}

\subsubsection{Uji Instrumen Penelitian}

\subsubsection{Uji Validitas}

Kriteria validitas dapat ditentukan dengan melihat nilai Pearson correlation dan Sig.(2-tailed).

- Jika $r$ hitung $>r$ tabel dan Sig < 0.05, maka butir dari variabel tersebut valid.

- Jika $r$ hitung < $r$ tabel dan Sig < 0.05, maka butir dari variabel tersebut tidak valid.

\subsubsection{Uji Reliabilitas}

Pengujian reliabilitas dilakukan dengan menggunakan Cronbach Alpha. Koefisien Cronbach Alpha yang > 0,4438 ( $=20)$ menunjukkan kehandalan (reliabilitas) instrumen (bila dilakukan penelitian ulang dengan waktu dan dimensi yang berbeda akan menghasilkan kesimpulan yang sama) dan jika koefisien Cronbach Alpha yang < 0,4438 menunjukkan kurang handalnya instrumen (bila variabelvariabel tersebut dilakukan penelitian ulang dengan waktu dan dimensi yang berbeda akan menghasilkan kesimpulan yang berbeda). Selain itu, Cronbach Alpha yang semakin mendekati 1 menunjukkan 
semakin tinggi konsistensi internal reliabilitasnya.

\subsubsection{Uji Asumsi Klasik}

\subsubsection{Uji Normalitas}

Pengujian normalitas pada penelitian ini dilakukan melalui uji normalitas dengan tes One sample Kolmogorov Smirnov dan analisis grafik normal probability plot.

\subsubsection{Uji Multikolinieritas}

Uji Multikolinieritas bertujuan untuk menguji apakah model regresi ditemukan memiliki korelasi antar variabel bebas (variabel independen).

Tolerance value $<0,10$ atau VIF $>10$ : terjadi multikolenearitas.

Tolerance value $>0,10$ atau VIF $<10$ : tidak terjadi multikolenearitas.

\subsubsection{Uji Heteroskedastisitas}

Penelitian ini menggunakan Scatter Plot dan Uji Glejser untuk meregresi nilai absolut residual terhadap variabel independen dengan menggunakan dasar pengambilan keputusan sebagai berikut:

Jika nilai Sig variabel independen $<0,05$ terjadi Heteroskedastisitas

Jika nilai Sig variabel independen $>0,05$ tidak terjadi Heteroskedastisitas.

\subsubsection{Analisis Regresi Linier Berganda}

Untuk menganalisis dan mengetahui tingkat signifikan dan variabel manakah yang sangat berpengaruh terhadap loyalitas. Dengan metode ini dapat dilihat hubungan antara $\mathrm{X}_{1}$ dengan $\mathrm{Y}, \mathrm{X}_{2}$ dengan Y. Regresi linier berganda adalah metode kuadrat terkecil (Ordinary Least Square). Adapun bentuk modelnya yaitu sebagai berikut :

$-Y=a+b_{1} X_{1}+b_{2} X_{2}+e$

- Dimana :
- $\quad Y=$ Variabel dependen (loyalitas)

- $X_{1}=$ Variabel Independen (kompensasi)

- $X_{2}=$ Variabel Independen (beban kerja)

- $a=$ konstanta $; b_{1}, b_{2}=$ koefisien regresi

- $e=$ Faktor pengganggu diluar model

\subsubsection{Analisis Koefisien Korelasi Berganda}

Analisis koefisien korelasi berganda (r) digunakan untuk menerangkan kekuatan dan arah hubungan antara variabel independen dan dipenden.

Adapun pedoman untuk memberikan interpretasi koefisien korelasi atau seberapa besar pengaruh variabel-variabel bebas (Independent) terhadap variabel terikat (Dependent).

\subsubsection{Analisis Koefisien Determinasi}

Koefisien determinasi (R2) pada intinya berguna untuk mengukur seberapa jauh kemampuan model dalam menerangkan variasi variabel dependen. Nilai koefisien determinasi adalah antara nol (0) sampai satu (1), $(0<\mathrm{R}<1)$. Nilai $\mathrm{R}$ yang kecil berarti kemampuan variabel-variabel independen dalam menjelaskan variasi variabel sangat terbatas. Nilai yang mendekati satu berarti variabel-variabel independen memberikan hampir semua informasi yang dibutuhkan untuk memprediksi variasi variabel dependen.

$\mathrm{KD}=\mathrm{r} 2 \times 100 \%$

Kriteria untuk analisis koefisien determinasi adalah :

a. Jika KD mendekati nol (0), maka pengaruh variabel independent terhadap variabel dependent lemah. 
b. Jika KD mendekati satu (1), berarti pengaruh variabel independent terhadap variabel dependent kuat. Sumber : Sugiyono (2012:250).

\subsubsection{Uji Hipotesis}

\subsubsection{Uji t (Uji Parsial)}

Uji ini digunakan untuk mengetahui signifikansi dari pengaruh variabel independen terhadap variabel dependen secara individual dan menganggap dependen yang lain konstan(Ghozali, 2011: 98). Signifikansi pengaruh tersebut dapat diestimasi dengan membandingkan antara nilai $\mathrm{t}$ tabel dengan nilai $t_{\text {hitung. }}$.

Bentuk pengujiannya adalah :

$\mathrm{H}_{0}$ : Tidak terdapat pengaruh variabel independen terhadap variabel dependen.

$\mathrm{H}_{1}$ : Terdapat pengaruh variabel independen terhadap variabel dependen.

Apabila nilai $t_{\text {hitung }}>t_{\text {tabel }}$ maka variabel independen secara individual mempengaruhi variabel independen, sebaliknya jika nilai $t_{\text {hitung }}<t_{\text {tabel }}$ maka variabel independen secara individual tidak mempengaruhi variabel dependen.

$t_{\text {hitung }}>t_{\text {tabel }}$ berarti $\mathrm{H}_{0}$ ditolak dan $\mathrm{H}_{1}$ diterima.

$t_{\text {hitung }}<t_{\text {tabel }}$ berartiH $H_{0}$ diterima dan $\mathrm{H}_{1}$ ditolak.

Uji $\mathrm{t}$ juga bisa dilihat pada tingkat signifikansinya :

- Jika tingkat signifikansi $<0,05$, maka $\mathrm{H}_{0}$ ditolak dan $\mathrm{H}_{1}$ diterima.

- Jika tingkat signifikansi > 0,05, maka $\mathrm{H}_{0}$ diterima dan $\mathrm{H}_{1}$ ditolak.

\subsubsection{Uji F (Uji Simultan)}

Uji ini digunakan untuk mengetahui pengaruh bersama-sama variabel bebas terhadap varibel terikat.

Bentuk pengujiannya adalah :

$\mathrm{H}_{0} \quad$ : Tidak terdapat pengaruh variabel independen terhadap variabel dependen.

$\mathrm{H}_{1}$ : Terdapat pengaruh variabel independen terhadap variabel dependen.

Dimana jika $\quad F_{\text {hitung }}>F_{\text {tabel}}$, maka $\mathrm{H}_{1}$ diterima atau secara bersama-sama variabel bebas dapat menerangkan variabel terikatnya secara serentak. Sebaliknya apabila $\mathrm{F}_{\text {hitung }}<\mathrm{F}_{\text {tabel }}$, maka $\mathrm{H}_{0}$ diterima atau secara bersama-sama variabel bebas tidak memiliki pengaruh terhadap variabel terikat. Untuk mengetahui signifikan atau tidak pengaruh secara bersama-sama variabel bebas terhadap variabel terikat maka digunakan probability sebesar 5\% $(\alpha$ $=0,05)$.

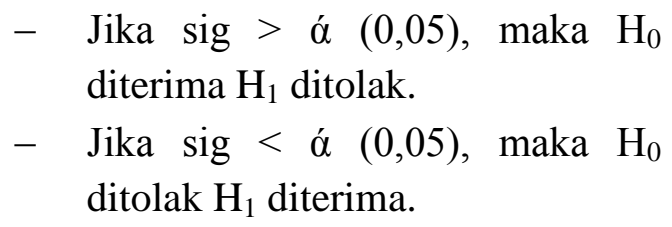

\subsection{Definisi Operasional Variabel dan Pengukuran Variabel \\ 3.7.1 Definisi Operasional}

Definisi operasional adalah operasionalisasi konsep agar dapat diteliti atau diukur melalui gejala-gejala yang ada. Agar penelitian ini dapat dilaksanakan sesuai dengan yang diharapkan, maka perlu dipahami berbagai unsur-unsur yang menjadi dasar dari suatu penelitian ilmiah yang termuat dalam operasionalisasi variabel penelitian. Secara lebih rinci, definisi operasional variabel adalah seperti pada tabel 3.5 dibawah ini. 
Tabel 3.1 Definisi Operasional Variabel

\begin{tabular}{|c|c|c|c|c|}
\hline Variabel & Dimensi & Indikator & $\begin{array}{l}\text { No } \\
\text { Kuesioner }\end{array}$ & Skala \\
\hline \multirow{12}{*}{$\begin{array}{l}\text { Kompensasi } \\
\left(\mathrm{X}_{1}\right)\end{array}$} & \multirow[t]{5}{*}{$\begin{array}{l}\text { Pembayaran } \\
\text { f inansial langsung }\end{array}$} & \multirow{2}{*}{$\begin{array}{l}\text { Gaji dan kebutuhan karyawan } \\
\text { Gaji dan posisi kerja karyawan }\end{array}$} & \multicolumn{2}{|l|}{1} \\
\hline & & & \multicolumn{2}{|l|}{2} \\
\hline & & $\begin{array}{l}\text { Gaji dan kemampuan kerja } \\
\text { karyawan }\end{array}$ & \multicolumn{2}{|l|}{3} \\
\hline & & Gaji dan motivasi karyawan & \multicolumn{2}{|l|}{4} \\
\hline & & $\begin{array}{l}\text { Bonvs dan insentifterhadap } \\
\text { semangat kerja karyawan }\end{array}$ & \multicolumn{2}{|l|}{5} \\
\hline & & $\begin{array}{l}\text { Bonvs dan insentif diterima secara } \\
\text { adil oleh karyawan. }\end{array}$ & \multicolumn{2}{|l|}{6} \\
\hline & \multirow[t]{2}{*}{$\begin{array}{l}\text { Pembayaran } \\
\text { finansia1 } \\
\text { lang sung }\end{array}$} & $\begin{array}{l}\text { Bonus dan insentif sesuai dengan } \\
\text { prestasi kerja karyawan }\end{array}$ & \multicolumn{2}{|l|}{7} \\
\hline & & Ansuransi ke sehatan yang tersed ia & 8 & Ordinal \\
\hline & \multirow[t]{4}{*}{ Kompetesi Sosia1 } & \multicolumn{3}{|l|}{$\begin{array}{l}\text { Ansuransi kesehatan memuakan } 9 \\
\text { karyawa }\end{array}$} \\
\hline & & Uang pesangon & \multicolumn{2}{|l|}{10} \\
\hline & & Tunjangan cuti & \multicolumn{2}{|l|}{11} \\
\hline & & Tunjangan hari raya & \multicolumn{2}{|l|}{12} \\
\hline Beban Kerja & \multirow[t]{9}{*}{ Beban wakts } & Masuk kerja Pulang kerja & \multicolumn{2}{|l|}{1} \\
\hline \multirow[t]{11}{*}{$\left(\mathrm{X}_{2}\right)$} & & Lembur (overtine) & 2 & \\
\hline & & Jam ist irahat & 3 & \\
\hline & & $\begin{array}{l}\text { Waktu yang cukup untuk } \\
\text { menyelesaikan pekerjaan }\end{array}$ & 4 & \\
\hline & & Bekerja dengan cepat & 5 & \\
\hline & & Kerja Shift & 6 & \\
\hline & & $\begin{array}{l}\text { Pekerjaan sesuai dengan } \\
\text { kemampuan }\end{array}$ & 7 & \\
\hline & & Pekerjaan dan konsentrasi & 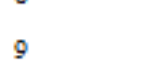 & \\
\hline & & Kond isi pengambilan keputusan & 10 & \\
\hline & \multirow{3}{*}{ Beban usaha mental } & Pekerjaan tidak membosankan & \multirow{2}{*}{\multicolumn{2}{|c|}{ ordinal }} \\
\hline & & $\begin{array}{l}\text { Pekerjaan tidak membebani } \\
\text { karyawan }\end{array}$ & & \\
\hline & & Konsentrasi kerja & \multicolumn{2}{|l|}{12} \\
\hline
\end{tabular}

\section{HASIL PENELITIAN DAN PEMBAHASAN \\ mengetahui pengaruh antar variabel penelitian.}

Deskripsi hasil penelitian akan diuraikan terlebih dahulu sebelum dilakukan analisis dan interpretasi data. Hasil perhitungan statistik disajikan dalam bentuk deskriptif untuk memaparkan deskripsi data, selanjutnya hasil penelitian diuraikan menggunakan analisis inferensial untuk

\subsection{Profil Responden}

Responden yang menjadi sampel dalam penelitian ini berjumlah 102 responden yang dibahas meliputi beberapa karakteristik, yaitu : jenis kelamin, pendidikan, jabatan, masa kerja dan usia. 
Adapun hasil yang didapat pada penelitian ini dah hasil olahan datanya dapat dilihat pada tabel-tabel berikut :

\section{Tabel 4.1 Profil Jenis Kelamin}

Responden

\begin{tabular}{clcc}
\hline No & Jenis Kelamin & $\begin{array}{c}\text { Jumlah } \\
\text { (orang) }\end{array}$ & $\%$ \\
\hline 1 & Laki-laki & 102 & 100 \\
2 & Perempuan & 0 & 0 \\
\hline & Jumlah & 102 & 100 \\
\hline
\end{tabular}

Sumber : Data primer yang diolah, 2016

Tabel 4.2 Profil Pendidikan

Terakhir Responden

\begin{tabular}{cccc}
\hline No & Usia (tahun) & $\begin{array}{c}\text { Jumlah } \\
\text { (orang) }\end{array}$ & $\%$ \\
\hline 1 & SMA & 65 & 64 \\
2 & D3 & 8 & 8 \\
3 & S1 & 28 & 27 \\
4 & S2 & 1 & 1 \\
\hline \multicolumn{4}{l}{ Sumber : Data primer yang diolah, 2016}
\end{tabular}

Tabel 4.3 Profil Kepangkatan Responden

\begin{tabular}{|c|c|c|c|}
\hline No & Jabatan & $\begin{array}{l}\text { Jumlah } \\
\text { (orang) }\end{array}$ & $\%$ \\
\hline 1 & Pelaksana & 73 & 72 \\
\hline \multirow[t]{2}{*}{2} & Staf & 29 & 28 \\
\hline & Jumlah & 102 & 100 \\
\hline
\end{tabular}

Sumber : Data primer yang diolah, 2016

\section{Tabel 4.4 Profil Masa Kerja}

\section{Responden}

\begin{tabular}{|c|c|c|c|}
\hline No & $\begin{array}{c}\text { Masa Kerja } \\
\text { (tahun) }\end{array}$ & $\begin{array}{l}\text { Jumlah } \\
\text { (orang) }\end{array}$ & $\%$ \\
\hline 1 & $1-5$ & 35 & 34 \\
\hline 2 & $6-10$ & 27 & 26 \\
\hline 3 & $11-15$ & 18 & 18 \\
\hline \multirow[t]{2}{*}{4} & $>15$ & 22 & 22 \\
\hline & Jumlah & 102 & 100 \\
\hline
\end{tabular}

Tabel 4.5 Profil Usia Responden

\begin{tabular}{cccc}
\hline No & $\begin{array}{l}\text { Usia } \\
\text { (tahun) }\end{array}$ & $\begin{array}{l}\text { Jumlah } \\
\text { (orang) }\end{array}$ & $\%$ \\
\hline 1 & $20-29$ & 55 & 54 \\
2 & $30-39$ & 38 & 37 \\
3 & $40-49$ & 5 & 5 \\
4 & $>50$ & 4 & 4 \\
\hline & Jumlah & 102 & 100 \\
\hline
\end{tabular}

Sumber : Data primer yang diolah, 2016

\subsection{Uji Validitas dan Reliabilitas Instrumen}

Sebelum kuesioner digunakan dalam penelitian ini, telah dilakukan uji coba terhadap 20 orang responden yang dipilih secara acak pada karyawan di Departemen Operasi PT. Pusri Palembang. Kemudian data hasil ujicoba tersebut dilakukan uji validitas dan reliabilitas terhadap instrumen (kuesioner) sebagai alat ukur dalam penelitian.

\subsubsection{Uji Validitas}

Pengujian ini dilakukan untuk menguji kesalahan setiap item pernyataan dalam mengukur variabel valid (sah). Dari hasil uji semua item pernyataan untuk setiap variabel mempunyai nilai signifikansi $<0,05$, dan semua $r$ hitung $>r$ table $(\mathrm{r}$ table df $20(\mathrm{~N}-2)=0.4438)$ sehingga semua pernyataan instrument valid. Hal ini berarti bahwa semua item yang dijadikan sebagai indikator terhadap variabel kompensasi menunjukkan valid dan dapat digunakan dalam penelitian ini.

\subsubsection{Uji Reliabilitas}

Hasil perhitungan nilai reliabilitas Cronbach Alpha untuk variabel Kompensasi, Beban Kerja kerja dan Loyalitas Karyawan, dikatakan reliabel jika Cronbach Alpha lebih besar dari 0.4438 (table $\mathrm{r}$, df20 $(\mathrm{N}-2)=0.4438)$ maka 
instrument dinyatakan reliable atau konsisten.

Variabel kompensasi, beban kerja dan loyalitas karyawan memiliki nilai Cronbach Alpha 0,977 dimana lebih besar dari 0,4438 maka semua instrumen dinyatakan reliabel.

\subsubsection{Uji Asumsi Klasik}

\subsubsection{Uji Normalitas}

Pengujian normalitas pada penelitian ini dilakukan melalui uji normalitas dengan tes One sample Kolmogorov Smirnov.

Tabel 4.6 Hasil uji normalitas dengan Kolmogorov Smirnov

One-Sample Kolmogorov-Smirnov Test

\begin{tabular}{|c|c|c|}
\hline & & $\begin{array}{l}\text { Unstandardiz } \\
\text { ed Residual }\end{array}$ \\
\hline $\mathrm{N}$ & & 102 \\
\hline \multirow[t]{2}{*}{ Normal Parameters ${ }^{a, b}$} & Mean & $0 \mathrm{E}-7$ \\
\hline & Std. Deviation & 4.20291812 \\
\hline \multirow[t]{3}{*}{ Most Extreme Differences } & Absolute & .095 \\
\hline & Positive & .095 \\
\hline & Negative & -.051 \\
\hline Kolmogorov-Smirnov Z & & .962 \\
\hline Asymp. Sig. (2-tailed) & & .313 \\
\hline
\end{tabular}

Sumber: Hasil Olah Data Penelitian, 2016.

Berdasarkan tabel diatas, didapat signifikasi 0.313 lebih besar dari 0.05 yang menyatakan bahwa data yang diuji berdistribusi normal.

\subsubsection{Uji Multikolinearitas}

Untuk mendeteksi adanya Multikolinearitas, maka dapat dilihat dengan besaran nilai VIF (Variance Inflation Factor) dan Tolerance.

Nilai Varian Inflation Factor (VIF) untuk kedua variabel independen berada dibawah 10, dan nilai Tolerance $>0.1$ hal ini menunjukkan bahwa antar variabel independen tidak saling berkaitan, sehingga data terbebas dari masalah multikolinieritas.

\subsubsection{Uji Heteroskedastisitas}

Untuk uji Heteroskedastisitas dengan uji Glejser pengambilan keputusan dalam uji Heteroskedastisitas ini yaitu jika Sig > 0.05, maka tidak terjadi Heteroskedastisitas, dan jika Sig < 0.05 maka terjadi Heteroskedastisitas. semua variabel memiliki nilai Sig > 0.05 maka tidak terjadi Heteroskedastisitas.

\subsubsection{Analisis Regresi Linier Berganda}

Untuk mengetahui signifikansi antar variabel, bisa dilihat dari tabel Correlations diatas. Jika nilai Sig $<0.05$ maka ada hubungan yang signifikan antara kedua variabel, sebaliknya jika nilai Sig > dari 0.05 maka ada hubungan yang tidak signifikan antara kedua variabel tersebut.

Dari tabel Correlations diatas dapat dilihat bahwa nilai Sig untuk variabel kompensasi adalah $=0.000$, lingkungan kerja $=0.000$ dan beban kerja $=0.003$. Semua variabel memiliki nilai $\mathrm{Sig}<$ dari 0.05, hal ini menyatakan terdapat hubungan yang signifikan antara masing masing variabel independen terhadap variabel dependen.

\subsubsection{Koefisien Korelasi (r) dan Koefisien Determinasi ( $\mathbf{R}^{2}$ )}

Dari hasil perhitungan analisis regresi linier berganda yang telah dilakukan nilai korelasi antara variabel independen dengan variabel dependen (r) dan koefisien determinasi $\left(\mathrm{R}^{2}\right)$ dapat dilihat pada tabel di bawah ini:

Tabel 4.7 Tabel model summary

Model Summary ${ }^{b}$

\begin{tabular}{|l|r|r|r|c|}
\hline Model & R & R Square & $\begin{array}{c}\text { Adjusted R } \\
\text { Square }\end{array}$ & $\begin{array}{c}\text { Std. Error of } \\
\text { the Estimate }\end{array}$ \\
\hline 1 & $.597^{\text {a }}$ & .357 & .337 & 4.26676 \\
\hline
\end{tabular}
a. Predictors: (Constant), Beban Kerja, Kompensasi, Ling
Kerja
b. Dependent Variable: Loyalitas Karyawan

Sumber: Hasil Olah Data Penelitian, 2016. 
Dari tabel diatas terlihat bahwa nilai korelasi antara variabel independen dengan variabel dependen adalah sebesar 0.597 menunjukkan bahwa terdapat hubungan yang cukup kuat diantara variabel dependen dan variabel independen, sedangkan nilai $\mathrm{R}$ (koefisien determinasi) sebesar 0.357 atau $35.7 \%$ menunjukkan bawah variabel kompensasi dan beban kerja mampu menjelaskan loyalitas karyawan sebesar $35.7 \%$ sedangkan sisanya $64.3 \%$ (100\% $35.7 \%$ ) dijelaskan oleh faktor lain yang tidak diteliti dalam penelitian ini seperti komitmen, gaya kepemimpinan, motivasi dan budaya organisasi.

\subsubsection{Uji Signifikasi Simultan (Uji F)}

Uji statistik F menunjukkan apakah semua variabel independent yang dimasukkan dalam model mempunyai pengaruh secara bersama-sama terhadap variabel dependen atau tidak.

\section{Tabel 4.8 Tabel ANOVA/Uji simultan}

\begin{tabular}{|c|c|c|c|c|c|c|}
\hline \multicolumn{7}{|c|}{ ANOVA ${ }^{a}$} \\
\hline \multicolumn{2}{|c|}{ Model } & $\begin{array}{l}\text { Sum of } \\
\text { Squares }\end{array}$ & df & Mean Square & $\mathrm{F}$ & Sig. \\
\hline \multirow[t]{3}{*}{1} & Regression & 989.138 & 3 & 329.713 & 18.111 & $.000^{b}$ \\
\hline & Residual & 1784.117 & 98 & 18.205 & & \\
\hline & Total & 2773.255 & 101 & & & \\
\hline
\end{tabular}

Sumber: Hasil Olah Data Penelitian, 2016.

Dari tabel 4.16 anova (uji F) dengan menggunakan df $=3$ diperoleh $F$ tabel sebesar 2.70 sedangkan $F$ hitungnya diperoleh sebesar 18.111 ( $\mathrm{F}$ hitung $>\mathrm{F}$ tabel), dengan nilai Sig $0.000<0.05$ sehingga dapat diketahui bahwa $\mathrm{H}_{0}$ diterima artinya secara keseluruhan kompensasi, dan beban kerja memberikan pengaruh secara signifikan terhadap loyalitas karyawan.

\subsubsection{Uji Parsial (Uji t)}

1. Nilai t-hitung kompensasi 5.380> $t_{\text {tabel }} 1.984$ dan Sig sebesar $0,000<$ 0.05 , artinya dengan kepercayaan sebesar 95\% dapat dinyatakan bahwa jika lingkungan kerja, beban kerja dianggap tetap, maka kompensasi berpengaruh positif dan signifikan terhadap loyalitas karyawan.

2. Nilai t-hitung beban kerja 2.014> $t_{\text {tabel }} 1.984$ dan Sigsebesar $0.047<$ 0.05 , artinya dengan kepercayaan sebesar 95\% dapat dinyatakan bahwa jika kompensasi, lingkungan kerja dianggap tetap, maka beban kerja berpengaruh positif dansignifikan terhadap loyalitas karyawan.

Hasil pengujian secara simultan menunjukkan adanya pengaruh positif dan signifikan antara kompensasi dan beban kerja terhadap loyalitas karyawan. Artinya semakin baik kompensasi dan beban kerja maka loyalitas karyawan akan meningkat.

Berdasarkan data hasil penelitian yang diperoleh, hasil regresi linier berganda, Maka persamaan regresi linier adalah

$Y=17.782+0.411 X_{1}+0.154 X_{3}$

Dimana :

$Y=$ Loyalitas karyawan

$X_{1}=$ Kompensasi

$X_{2}=$ Beban kerja

Nilai konstanta loyalitas sebesar 17.782 menunjukkan nilai murni variabel terikat tanpa dipengaruhi variabel kompensasi dan beban kerja.

Hasil persamaan koefisien regresi variabel kompensasi sebesar 0.411, ini berarti setiap peningkatan variabel kompensasi maka dapat diprediksi bahwa variabel loyalitas ikut naik 0.411 . Koefisien regresi variabel beban kerja 
sebesar 0.154, ini berarti setiap peningkatan variabel beban kerja maka dapat diprediksi bahwa variabel loyalitas ikut naik 0.154 .

\subsubsection{Uji Hipotesis}

1. Variabel kompensasi $\left(\mathrm{X}_{1}\right)$

a. Nilai t-hitung $=5.380>$ $t_{\text {tabel }} 1.984$,maka $\mathrm{H}_{0}$ ditolak dan $\mathrm{H}_{1}$ diterima.

b. Nilai Sig $=0.000<0.05$, variabel independen kompensasi memberikan pengaruh secara positif dan signifikan terhadap variabel dependen (loyalitas karyawan). Dengan kata lain hipotesis "H1 : Kompensasi berpengaruh terhadap loyalitas karyawan"dapat diterima.

2. Variabel beban kerja $\left(X_{2}\right)$

a. Nilai t-hitung $=2.014>$ $t_{\text {tabel }} 1.984, \mathrm{makaH}_{0}$ ditolak dan $\mathrm{H}_{1}$ diterima.

b. Nilai Sigsebesar $=0.047<0.05$, variabel independen beban kerja memberikan pengaruh secara positif dan signifikan terhadap variabel dependen (loyalitas karyawan). Dengan kata lain hipotesis "H3 : Beban kerja berpengaruh terhadap loyalitas karyawan"dapat diterima.

3. Kompensasi dan beban kerja secara simultan berpengaruh terhadap loyalitas karyawan di Departemen Operasi PT. Pusri Palembang.

a. Nilai F-hitung (18.111)>t_tabel (2.70), maka $\mathrm{H}_{0}$ ditolak dan $\mathrm{H}_{1}$ diterima. b. Nilai Sig sebesar $=$ $0.000<\quad 0.05, \quad$ variabel independen (kompensasi dan beban kerja) secara simultan memberikan pengaruh secara positif dan signifikan terhadap variabel dependen (loyalitas karyawan). Dengan kata lain hipotesis "H4 : Kompensasi dan beban kerja secara simultan berpengaruh terhadap loyalitas karyawan" dapat diterima.

4. Kompensasi berpengaruh dominan terhadap loyalitas karyawan di Departemen Operasi PT. Pusri Palembang.

a. Nilai t-hitung variabel kompensasi mempunyai nilai terbesar yaitu 5.380 >nilai t_hitung dari variabel dan beban kerja.

b. Nilai Sig variabel kompensasi $0.000<$ nilai variabel independen dan beban kerja. Dengan kata lain hipotesis "H5 : Kompensasi berpengaruh dominan terhadap loyalitas karyawan." Dapat diterima.

\subsection{Pembahasan}

Dari hasil penelitian diatas dapat diketahui bahwa variabel independen (variabel kompensasi, dan beban kerja) memberikan pengaruh signifikan terhadap variabel dependen (loyalitas karyawan). Hasil ini relevan dengan hasil penelitian yang dilakukan oleh Pratama (2014) yang menyatakan bahwa variabel kompensasi dan beban kerja secara simultan berpengaruh secara positif dan signifikan terhadap loyalitas karyawan. Penelitian lain yang mendukung yaitu penelitian Muhammad (2016), menunjukkan bahwa kompensasi dan beban kerja secara simultan memberikan pengaruh positif dan signifikan terhadap kinerja karyawan yang menimbulkan kepuasan kerja sehingga loyalitas karyawan akan meningkat. 


\subsubsection{Pengaruh Variabel Kompensasi (X) terhadap Loyalitas Karyawan (Y)}

Hasil uji hipotesis membuktikan adanya pengaruh yang positif dan signifikan dari variabel kompensasi terhadap loyalitas karyawan. Hasil penelitian ini didukung oleh penelitian Juliani (2015) yang menyatakan bahwa kompensasi memiliki pengaruh positif dengan loyalitas karyawan. Penelitian lain yang mendukung yaitu penelitian Pratama (2014), bahwa kompensasi memberikan pengaruh yang paling dominan terhadap loyalitas karyawan.

Steers \& Porter (1983 : 520) menyatakan bahwa loyalitas akan tercipta apabila karyawan tercukupi dalam memenuhi kebutuhan hidup dari pekerjaannya, sehingga mereka betah bekerja dalam suatu perusahaan. Teori lain yang mendukung adalah Handoko (2000 : 193) yang menyatakan bahwa kepuasan akan kompensasi dapat mempengaruhi perilaku karyawan untuk bekerja lebih semangat dan memacu tingginya kinerja.

\subsubsection{Pengaruh Beban Kerja $\left(X_{2}\right)$} Terhadap Loyalitas Karyawan (Y)

Hasil uji hipotesis membuktikan adanya pengaruh yang positif dan signifikan dari variabel beban kerja terhadap loyalitas karyawan. Hasil penelitian ini didukung oleh penelitian Pratama (2014), yang menyatakan dalam penelitiannya bahwa beban kerja memberikan pengaruh yang positif dan signifikan terhadap loyalitas karyawan. Teori mengenai beban kerja menurut Kirmeyer \& Dougherty (1988), menyatakan bahwa beban kerja yang berlebihan akan mempengaruhi kepuasan kerja karyawan dan kinerja karyawan. Hal tersebut. akan berdampak terhadap loyalitas karyawan. Handoko (2001) menyatakan bahwa faktor yang mempengaruhi loyalitas yaitu beban kerja yang berlebihan, tekanan atau desakan waktu, frustasi dan stress, konflik antar pribadi dan stress.

\section{KESIMPULAN DAN SARAN}

\subsection{Kesimpulan}

Berdasarkan hasil pembahasan yang telah diuraikan, maka dapat disimpulkan :

1. Kompensasi berpengaruh positif dan signifikan terhadap loyalitas karyawan di Departemen Operasi PT. Pusri Palembang.

2. Beban kerja berpengaruh positif dan signifikan terhadap loyalitas karyawan di Departemen Operasi PT. Pusri Palembang.

3. Kompensasi dan beban kerja secara simultan berpengaruh terhadap loyalitas karyawan di Departemen Operasi PT. Pusri Palembang.

4. Kompensasi mempunyai pengaruh paling dominan terhadap loyalitas karyawan di Departemen Operasi PT. Pusri Palembang.

\subsection{Saran}

Berdasarkan kesimpulan di atas, maka saran yang dapat diberikan adalah sebagai berikut:

1. Loyalitas karyawan di Departemen Operasi PT. Pusri Palembang dapat ditingkatkan dengan dengan memberikan kompensasi yang memuaskan. Dari hasil survey menunjukkan bahwa $88.24 \%$ responden menyatakan bonus dan insentif yang diterima bisa meningkatkan semangat kerja yang berdampak kepada loyalitas karyawan. 
2. Beban kerja berpengaruh signifikan terhadap loyalitas karyawan. Perusahaan diharapkan bisa mengkondisikan beban kerja yang optimal terhadap karyawan. Dari hasil survey menunjukkan $87.27 \%$ responden menyatakan bahwa tersedianya waktu yang cukup dalam menyelesaikan pekerjaan membuat karyawan bekerja dengan baik dan tidak terbebani, hal ini akan meningkatkan loyalitas karyawan di Departemen Operasi PT. Pusri Palembang bisa meningkat.

3. Dari data dapat disimpulkan bahwa kompensasi berpengaruh dominan terhadap loyalitas karyawan di Departemen Operasi PT. Pusri Palembang. Ini berarti, pemberian kompensasi yang baik dan memenuhi kepuasan karyawan dapat meningkatkan loyalitas karyawan secara signifikan.

4. Untuk penelitian selanjutnya, diharapkan agar menambah variabelvariabel lain sebagai indikator dalam penelitian lanjutan. Hal ini karena masih adanya variabel-variabel lain yang dapat meningkatkan loyalitas karyawan seperti komitmen, gaya kepemimpinan, motivasi dan budaya organisasi.

\section{DAFTAR PUSTAKA}

Amanah, Laelatul at al. 2015. Pengaruh lingkungan kerja, motivasi dan perilaku kepemimpinan terhadap loyalitas karyawan yayasan Samudera Ilmu Semarang. Journal of Management. ISSN : 2502-7689.

Dessler, Gary. 2007. Manajemen Sumber Daya Manusia. Jilid2. Jakarta : Pt. Indeks.
Dessler, Gary. 2015. Human Resource Management (14 29th edition). Jakarta :Salemba Empat.

Fajariani, Ni Putu Eka dan Surya, I.B.Ketut. $2015 . \quad$ Pengaruh pengalaman kerja dan kepemimpinan transformation terhadap loyalitas karyawan. E-Jurnal Manajemen Unud, Vol. 4, No. 4, 2015: 930-942.

Ghozali, Imam. 2011. Aplikasi Analisis Multivariate Dengan Program SPSS 19 (edisi kelima) Semarang : Universitas Diponegoro.

Gouzali, Saydam. 2008. Manajemen Sumber Daya Manusia jilid 1. Jakarta : Gunung agung.

Hani, T. Handoko. 2008. Manajemen Personalia dan Sumber Daya Manusia (edisi 2). Yogyakarta : BPFE.

Hasibuan, S.P. Malayu. 2009. Manajemen Sumber Daya Manusia, cetakan ketujuh. Jakarta : PT Bumi Aksara.

Hasibuan, S.P. Malayu. 2010. Manajemen Sumber Daya Manusia, edisi revisi. Jakarta : PT Bumi Aksara.

Juliani, Retno Djohar. 2015. Pengaruh Kompensasi terhadap Loyalitas Karyawan, Jurnal Ekonomi dan Bisnis Universitas Pandanaran Semarang, Vol No 2.

Kirmeyer, S.L. \& Dougherty, T.W. (1988). Work load, tension, and coping: Moderating effect of supervisor support. Personnel Psychology, 41, 125139.

Lestari, Puji. 2015. Hubungan antara pengembangan karir dan pemberian insentif terhadap loyalitas kerja 
karyawan pada PT. KOMATSU REMANUFACTURING ASIA di Balikpapan. eJournal Psikologi, 2015,4 (2): 131-143 ISSN 24770000, Universitas Mulawarman.

Luthans, F. 2005. Organizational Behavior. New York : Mcgraw-Hill.

Maharani, Ni Made at al. 2013 Pengaruh Insentif terhadap Loyalitas Karyawan Studi pada Karyawan Tetap PT. SIER (Persero) Surabaya, Universitas Brawijaya. Jurnal Administrasi Bisnis VOL 2, NO 2.

Malayu,S.P. Hasibuan. 2007. Manajemen Sumber Daya Manusia. Jakarta : Pt. Bumi Aksara.

Milkovich, George T. Newman. (2008). Compensation (Ninth Edition). New York : International Edition, Mc Graw Hill.

M. Kadarisman. 2014. Manajemen Kompensasi. Jakarta : $\mathrm{Pt}$. Rajjagrafindopersada.

Mathis, Robert L dan Jackson, John H. 2006. Manajemen Sumber Daya Manusia, Edisi 10. Jakarta : Salemba Empat.

Mehta, S., Singh, T., Bhakar, S., \& Sinha, B. (2010). Employee Loyalty Towards Organization-A study of Academician.

Int.J.Buss.Mgt.Eco.Res., Vol 1(1), 98-108.

Mondy, Wayne R. 2008. Manajemen Sumber Daya Manusia. Edisi Kesepuluh, Jilid 2 Jakarta : Erlangga.
Mondy, W and Noe, R, M. (1996). Human Resource Management. Texas : Prentice Hall, Inc.

Muhadjir, Noeng. 1996. Metodologi Penelitian Kualitatif. Edisi Ke-3. Yogyakarta : Rake Sarasin.

Powers, Edward L. 2000. Employee Loyalty in the New Millenium. S.A.M. Advance Management Journal. Summer, Vol. 65 (3): 4-8.30

Pratama, Adhitia, at al. 2015. Pengaruh Kompensasi, Lingkungan Kerja, dan Beban Kerja Terhadap Loyalitas Karyawan Melalui Kepuasan Kerja ( Studi Kasus Pada Karyawan PT. Kawasan Berikat Nusantara Persero Jakarta). Jurnal Ilmu Administrasi Bisnis, Volume 4, Nomor 1.

Safitri, Rahmadana. 2015. Pengaruh Kompensasi terhadap loyalitas karyawan PT. Putera Lautan Kumala Lines Samarinda. jurnal Administrasi Bisnis, Universitas Mulawarman.

Sedarmayanti. 2009. Tata Kerja dan Produktivitas kerja. Bandung : CV. Mandar Maju.

Sedarmayanti. 2016. Manajemen Sumber Daya Manusia. Bandung : PT. Refika Aditama.

Schultz, D., Schultz, S E. 2006. Psycology \& Work Today (Ninth Edition). New Jersey : Pearson Education. Inc.

Soleman, Aminah , 2011, Analisis Beban Kerja Ditinjau Dari Faktor Usia Dengan Pendekatan. Recommended Weight Limit (Studi Kasus Mahasiswa Upatti Poka). Jurnal Arika, Vol. 05. No. 2 (Agustus 2011). ISSN: 1978-1105. 
Steers, R.M dan Porter, L.W. 1983. Motivational and Work Behaviour. New York : Mc Graw Hill Book Company.

Sugiyono. 2009. Metode Penelitian Kuantitatif Kualitatif dan $R \& D$. Bandung : CV Alfabeta.
Terry, George R. 2006. Prinsip-Prinsip Manajemen, Penerjemah Smith. Jakarta : PT. Bumi Aksara.

Widiyanto, Joko. 2012. SPSS For Windows. Surakarta: Badan Penerbit FKIP Universitas Muhammadiyah Surakarta. 